\title{
Chemical composition of Lablab purpureus and Vigna unguiculata and their subsequent effects on methane production in Xhosa lop-eared goats
}

\author{
S. Washaya ${ }^{1,2 \#}$, J. Mupangwa ${ }^{2} \&$ V. Muchenje ${ }^{2}$ \\ 1 Africa University, Department of Agriculture and Natural Resources, P.O. Box 1320, Mutare, Zimbabwe \\ ${ }^{2}$ University of Fort Hare, Faculty of Science and Agriculture, Department of Livestock and Pasture Science, P. Bag \\ X1314, Alice 5700, South Africa
}

(Received 5 October 2017; Accepted 8 January 2018; First published online 6 February 2018)

\begin{abstract}
The objective of this study was to evaluate the nutritive value and anti-nutrient contents of Lablab purpureus (Lablab) and Vigna unguiculata (cowpea) and their effects on methane production in goats. Legume forages were grown and harvested at three stages of growth of pre-anthesis, anthesis, and post anthesis. Samples were collected at each stage and examined for proximate composition, total phenolics, condensed tannins, and saponins using standard methods. Hay was harvested at the anthesis stage and used in a growth study to evaluate the effects of forage legumes on methane production. Eighteen one-yearold goats, nine males and nine females, were used in the feeding trial. The goats were subjected to three treatment diets with six goats in each treatment, representing both sexes equally, for 60 days in a complete randomized design. Methane was measured with a laser methane detector (LMD). Cowpea showed higher ash (13.11\%), acid detergent fibre (ADF) (38.42\%), and crude protein (CP) $(20.23 \%)$ than Lablab, which had values of $11.45 \%, 36.17 \%$, and $19 \%$, for ash, $A D F$, and $\mathrm{CP}$, respectively. Lablab had significantly higher fat content $(2.41 \%)$, neutral detergent fibre (NDF) $(49.27 \%)$, and hemicellulose $(13.07 \%)$ than cowpea $(2.1 \%$, $46.91 \%$, and $8.48 \%$, respectively). The tannin, phenolic, and saponin content were influenced significantly by forage species and stage of growth. The diet and sex of the animal affected enteric methane production significantly. Forage legumes met animal requirements for fat, ADF, NDF, and CP. The energy and tannin levels of forage legumes were shown to reduce enteric methane production in goats.
\end{abstract}

Keywords: Forage legumes, nutritive value, small ruminants

\#Corresponding author: jabulaniwashay@yahoo.com

\section{Introduction}

Livestock production is a critical and perhaps the most successful business enterprise for underprivileged small-scale farmers that live in marginalized drought-prone areas. Nevertheless, this lucrative business is characterized by severe animal feed shortages, particularly during the dry season. Furthermore, changes in the climate of the southern hemisphere are likely to influence feed availability (Scholtz et al., 2013; Meissner et al., 2013). Many studies have focused on strategies to improve animal nutrition during dry periods. One such proposal was the use of improved pasture grasses and forage legumes (Mapiye et al., 2007). Improved pasture grasses provide sufficient metabolizable energy (ME), averaging between $8 \mathrm{ME} \mathrm{MJ/kg} \mathrm{dry} \mathrm{matter} \mathrm{(DM)} \mathrm{and} 12 \mathrm{ME} \mathrm{MJ/kg} \mathrm{DM} \mathrm{(McDonald} \mathrm{et} \mathrm{al.,} \mathrm{2011).} \mathrm{However,}$ they tend to have inadequate protein, especially in the dry season. Conversely, forage legumes provide enough protein, ranging from $12 \%$ to as high as $25 \%$ (McDonald et al., 2011) for maintenance and production, depending on the species. The use of legumes has also been limited by the availability of fermentable fibre (Mupangwa, 2000). Although legumes provide enough proteins, the amount of their fermentable carbohydrates tends to be limiting. Therefore, in most intensive systems, their use is usually of a supplemental nature to pasture grasses (Jingura et al., 2001). The amount of biomass is crucially important, although the nutritive value of the forages is of concern to livestock farmers. For pasture legumes and grass 
forages, biomass and age are generally negatively correlated with forage quality. Nutritive value has been linked to a number of factors, ranging from species to harvesting and curing methods. Furthermore, as reported by Mupangwa (2000), the stage of harvesting of most legume forages influences their nutritive value significantly. A similar conclusion was reached by Jingura et al. (2001). In addition, legume forages are known to contain high levels of anti-nutrients that form complexes with proteins and carbohydrates, rendering them unavailable. As a result of these limiting factors, it is necessary to evaluate the amount and extent of these complexities to validate the available protein. The presence of tannins and low fibre content can be advantageous in mitigating enteric methane $\left(\mathrm{CH}_{4}\right)$ production. Valenciaga et al. (2009) reported that forage legumes possess lower levels of soluble carbohydrate content compared to grasses, which can influence methane production. Soluble carbohydrates, such as starch, are easily fermented, resulting in high levels of free hydrogen $\left(\mathrm{H}_{2}\right)$, which promotes methanogenesis. On the other hand, tannins have been reported to decrease the number of cellulolytic bacteria (McSweeny et al., 2001), shift short-chain fatty acid (SCFA) production, and reduce DM and organic matter digestibility (OMD) (Hess et al., 2006; Abdalla et al., 2007; Animut et al., 2008; Tiemann et al., 2008), all of which stimulate the release of high $\mathrm{H}_{2}$.

Enteric $\mathrm{CH}_{4}$ production in ruminants accounts for about $11-17 \%$ of global methane (Storm et al., 2012). Methane arises from the activity of bacterial agents, called methanogens, in the rumen. These organisms use $\mathrm{H}_{2}$ to reduce carbon dioxide $\left(\mathrm{CO}_{2}\right)$. By so doing, they prevent the accumulation of reducing equivalents, which are known to impede ruminal fermentation. Goats are ruminant animals and produce enteric $\mathrm{CH}_{4}$. As reported by Du Toit et al. (2013), South African goats produce in the range of 15 to $17 \mathrm{~g} / \mathrm{kg}$ DM methane per day. Methane as a greenhouse gas (GHG) is a cause for concern in global warming (Storm et al., 2012). This has resulted in enormous research work that sought to elucidate and quantify the amount of gas produced by ruminant animals. Detailed reviews were done by Storm et al. (2012) and Moss et al. (2000), which highlighted the methods by which enteric $\mathrm{CH}_{4}$ from ruminant animals can be quantified. Regardless of the effectiveness of any method, the greatest challenge has been practical applicability of these enteric measurement methods. In these reviews, it is clear that ruminant animals are contributing to GHGs chiefly in the form of $\mathrm{CH}_{4}$. Therefore, the objective of this study was to evaluate the nutritive value, anti-nutrient content, and effects of Lablab purpureus and Vigna unguiculata on enteric $\mathrm{CH}_{4}$ production in goats.

\section{Materials and Methods}

The research was conducted at the University of Fort Hare Research Farm, Eastern Cape, South Africa, during the summer season in November 2014. The farm is located at a latitude of $32^{\circ} 46^{\prime} S$ and longitude $26^{\circ} 50^{\prime} \mathrm{E}$, at an altitude of 535 metres above sea level. It has a warm temperate climate with an average annual rainfall of about $575 \mathrm{~mm}$, which is received mainly during the summer months of November to March. The maximum temperature is $24.6^{\circ} \mathrm{C}$, minimum temperature is $11.1^{\circ} \mathrm{C}$, and average temperature is $17.8{ }^{\circ} \mathrm{C}$. The soils are deep and alluvial, of the Oakleaf form (Oa), belonging to the Ritchie family, according to the South African system of soil classification (Soil Classification Working Group (SCWG), 1991). According to the soil map of the world, the soils are Eutric Fluvisols (Fle). The vegetation is dominated by grasses such as Themeda triandra and Cympogon plurinodis with woody plants such as Acacia karro and shrubs encroaching the grazing lands (Mucina \& Rutherford, 2006).

The forage legumes $L$ purpureus and $V$. unguiculata were each grown in the 2014/15 season. Each legume was established in rows $0.60 \mathrm{~m}$ by $0.30 \mathrm{~m}$ in plots, two for each forage legume, measuring $16 \times 32$ $\mathrm{m}$, at Fort Hare Research Farm. A basal fertilizer of single superphosphate at $300 \mathrm{~kg} / \mathrm{ha}$ was applied on the day of planting. Legumes were grown under dry land conditions with no irrigation. The experiment was a $2 x$ 3 factorial experiment in a completely randomized design to examine the effects of forage legumes (Lablab and cowpea) and stage of growth (pre-anthesis, anthesis and post-anthesis) on nutrient, tannin, saponin and phenolic content. Three legume samples were cut randomly using a $0.5 \mathrm{~m}^{2}$ quadrant from each block to a $10-\mathrm{cm}$ stubble height. These samples were harvested from each block, making a total of 12 samples (six for each forage species). Twenty percent of the samples were oven dried at $60^{\circ} \mathrm{C}$ for 48 hours and stored at room temperature for further analysis. The dried legume samples were milled through a 1-mm screen. Triplicate samples of each legume were analysed for crude protein (CP) using Kjeldahl's procedure (AOAC, 2005), while neutral detergent fibre (NDF) and acid detergent fibre (ADF) were analysed by methods described by Goering \& Van Soest (1970). Total ash was obtained by igniting a dried sample in a muffle furnace at $500{ }^{\circ} \mathrm{C}$ for 24 hours and cooled to room temperature before determining ash content by difference. Pulverised samples with an average weight of $2 \mathrm{~g}$ were soaked in separate conical flasks with 50 $\mathrm{ml}$ organic solvents, which included acetone, methanol, ethanol and water and shaken in an orbital shaker (Gallenkamp 202 llanga Trading cc.) for 24 hours. The crude extracts were filtered using a Buchner funnel and Whatman No. 1 filter paper. 
Phenol determination was estimated spectrophotometrically using the Folin-Ciocalteu method as described by Samatha et al. (2012) with some modifications. The amounts of $0.5 \mathrm{~mL}$ of the plant extracts (1 $\mathrm{mg} / \mathrm{ml}$ ) and standard gallic acid with levels ranging from $0.02 \mathrm{mg} / \mathrm{ml}$ to $0.1 \mathrm{mg} / \mathrm{ml}$ were pipetted into different test tubes. To this, $2.5 \mathrm{ml} \mathrm{10 \%} \mathrm{(v/v)} \mathrm{Folin-Ciocalteu's} \mathrm{reagent,} \mathrm{prepared} \mathrm{in} \mathrm{distilled} \mathrm{water,} \mathrm{was} \mathrm{added} \mathrm{and} \mathrm{the}$ mixture was vortexed. The reaction was allowed to stand at room temperature for about 5 mins. After 5 mins, $2 \mathrm{ml} 7.5 \%(\mathrm{w} / \mathrm{v})$ anhydrous sodium carbonate was added to the solution, vortexed and incubated at $40^{\circ} \mathrm{C}$ for 30 mins. A control solution, which had neither extract nor gallic acid, was used as a blank. After incubation, the absorbance was measured at $765 \mathrm{~nm}$ using an AJI-C03 UV-Vis spectrophotometer (METTLER TOLEDO). The experiment was done in triplicate. The phenol content was extrapolated from the gallic acid standard/calibration graph equation: $y=0.0091 x-0.0527, R^{2} 0.9979$, and was expressed as $\mathrm{mg}$ gallic acid equivalent (GAE)/g DM from the equation:

$\mathrm{TP}=\mathrm{CV} / \mathrm{m}$

Where: TP is total phenolics

$C$ is the concentration as derived from the calibration curve equation in $\mathrm{mg} / \mathrm{ml}$

$\mathrm{V}$ is the volume of the extract used in the assay in $\mathrm{ml}$

$\mathrm{m}$ is the mass of the extract used in the assay in $\mathrm{g}$

The total proanthocyanidin was determined using a procedure described by Sun et al. (1998). A mixture containing $3 \mathrm{ml}$ vanillin-methanol $(4 \% \mathrm{w} / \mathrm{v}), 1.5 \mathrm{ml}$ hydrochloric acid, and standard catechin was added to $0.5 \mathrm{ml} 1 \mathrm{mg} / \mathrm{ml}$ extract solution at various concentrations from $0.02 \mathrm{mg} / \mathrm{mL}$ to $1 \mathrm{mg} / \mathrm{mL}$. The mixture was vortexed and allowed to stand for $15 \mathrm{~min}$ at room temperature. A blank control solution was used, which had neither extract nor catechin. The absorbance was measured at $500 \mathrm{~nm}$ using a UV-3000 PC spectrophotometer. Triplicate samples for each forage were used in this experiment. The proanthocyanidin content was evaluated using a calibration curve equation, namely $y=0.0014 x+0.015, R^{2} 0.9965$, and was expressed as $\mathrm{mg}$ catechin equivalent per gDM using the formula, $\mathrm{CV} / \mathrm{m}$, as referred to above.

The saponin content in the plant extracts was determined using the method described by Omoruyi et al. (2012). The procedure included mixing $1 \mathrm{mg}$ of the various solvent extracts with $50 \mathrm{ml} 20 \%$ ethanol in a shaker for $30 \mathrm{~min}$. This was then heated in a water bath at $55{ }^{\circ} \mathrm{C}$ for 4 hours with continuous stirring. After heating, the mixture was filtered and the residue was re-extracted with another $20 \mathrm{ml} 20 \%$ ethanol. The combined extracts were reduced to $40 \mathrm{ml}$ in a water bath at $90{ }^{\circ} \mathrm{C}$. The concentrated solution was then transferred into a $250 \mathrm{ml}$ separating funnel and extracted twice using $20 \mathrm{ml}$ diethyl ether. The ether layer was discarded, while the aqueous layer was retained, and $60 \mathrm{ml} n$-butanol was added. The $n$-butanol extracts were washed twice with $10 \mathrm{ml} 5 \%$ sodium chloride. The butanol layer was collected and evaporated in a water bath and later oven dried at $40{ }^{\circ} \mathrm{C}$ to a constant weight. This was done in triplicate and the percentage saponin content was calculated using the formula:

$\%$ saponin $=$ final weight of sample $/$ initial weight of sample $\times 100$

Eighteen goats were used in this experiment. The average age of goats was 12 months and they had an average live weight of $14.2 \pm 0.24 \mathrm{~kg}$, with equal representation for sexes (nine castrated males and nine empty females). Goats were dewormed using niclosamide 20\% (Lintex L), and dipping was done with a pouron acaricide (Coopers Redline). They were subjected to three treatments: treatment $1\left(\mathrm{~T}_{1}\right): 71 \%$ Vigna hay, $19 \%$ Katambora hay, salt $(0.5 \%)$, molasses (3\%), maize (5\%), and mineral vitamin premix (1.5\%); treatment $2\left(T_{2}\right): 90 \%$ lamb and ewe pellet plus 10\% Katambora grass hay; and treatment $3\left(T_{3}\right): 72 \%$ Lablab hay $19 \%$ Katambora hay, salt $(0.5 \%)$, molasses $(2 \%)$ maize $(5 \%)$, and mineral vitamin premix $(1.5 \%)$. T2 was the positive control diet. All diets were formulated to contain CP and energy to meet the minimum recommendation for intensive feeding (i.e. 14\% CP and $9 \mathrm{MJ} \mathrm{ME} / \mathrm{kg} \mathrm{DM}$ ), according to NRC (2001). Animals were injected with a mineral and vitamin complex (Cipla Agrimed, Pretoria, South Africa) prior to housing and after every 14 days. Animals were housed individually in metabolic pens measuring $1.5 \times 1.0 \mathrm{~m}$ and acclimatized to the environment and experimental conditions for two weeks; this was followed by 40 days of growth/feeding trial and 6 days of digestibility trial, respectively. The experiment was arranged in a complete randomized design with $3 \times 2$ factorial arrangements (three diets and two sexes). Animals were housed according to sex. Animals were fed in two equal portions at 08:00 and 15:00 hour daily and the amount offered was adjusted based on bodyweight measured every 15 days. Clean water was available to animals ad libitum.

Methane was measured using an LMD (Crowcon Detection Instruments Ltd., Oxfordshire, United Kingdom), weekly from the adaptation period when animals were resting, feeding and ruminating, then daily 
for the last seven days of the trial. The LMD equipment measures the concentration of $\mathrm{CH}_{4}$ between the equipment and the target point. It is based on infrared absorption spectroscopy and measures $\mathrm{CH}_{4}$ values as a plume. Hence the measurements are in parts per million-metre (ppm-m). The equipment operates normally in the temperature range between 0 and $40^{\circ} \mathrm{C}$, in the humidity range of $20-90 \%$, with a reaction time of 0.1 seconds. The LMD can detect $\mathrm{CH}_{4}$ concentrations between 1 and $50,000 \mathrm{ppm}$ within a distance of up to 150 $\mathrm{m}$. Gas column density was measured by directing the auxiliary LMD targeting (visible $\mathrm{HeNe}$ ) laser beam at the nostrils of goats for a maximum of five minutes per animal at a distance of $1.5 \mathrm{~m}$. This distance was considered safe enough not to disturb animal activity, as described by Chagunda et al. (2009). All measurements were taken at approximately the same time of day (morning and late afternoon). Three measurements were taken from each animal at each activity and the average value was calculated.

Methane eructed was determined per each activity using standard respiratory coefficients per activity, then translated to an equivalent emission per day. Methane production was also evaluated in relation to dry matter intake (DMI) consumed.

\section{Methane eructed during activity}

$$
M_{T V}=M_{M D} \times T_{V r} / 10^{6} \mathrm{ml} \text { (Chagunda et al., 2009) }
$$

Where: $M_{T V}$ is the enteric methane in breath in $\mathrm{ml}$ during ruminating

$M_{M D}$ is the enteric methane detected by LMD converted from ppm-m to $\mathrm{ml}$

$\mathrm{T}_{\mathrm{Vr}}$ is the tidal volume during different activities

Additionally, $\mathrm{T}_{\mathrm{Vr}}$ feeding $=620 \mathrm{ml}, \mathrm{T}_{\mathrm{Vr}}$ standing $=760 \mathrm{ml}, \mathrm{T}_{\mathrm{Vr}}$ ruminating $=760 \mathrm{ml}$

Tidal volume (feeding) $=3100 \mathrm{ml}$, tidal volume (standing) $=3800 \mathrm{ml}$ for dairy animals. These were then converted using livestock units to represent goats, where $0.5 \mathrm{LU}$ cow is equivalent to 0.1 livestock unit (LU) goats (Chilonda \& Otte, 2006) for sub-Saharan Africa.

\section{Methane eructed per activity per day}

$$
M_{T T A}=M_{T V} \times R_{T A} \text { (Chagunda et al., 2009) }
$$

Where: $\mathrm{M}_{\mathrm{TTA}}$ is the amount of enteric methane produced during an activity (rumination, feeding, just standing).

\section{Methane eructed per day}

$$
M_{D}=\operatorname{MTTA} \times\left(T_{D} \times R_{T A}\right) \text { ml/day (Chagunda et al., 2009) }
$$

Where: $M_{D}$ is daily enteric methane

$T_{D}$ is daytime in seconds

$\mathrm{R}_{\mathrm{TA}}$ is total time spent on activity

$R_{T A}$ standing $=1440, R_{T A}$ feeding $=2880$, and $R_{T A}$ ruminating $=7200$

By substitution and use of specific density conversion factor, daily enteric methane in grams (MDG) is: $M_{D G}(\mathrm{~g} /$ day $)=M_{D} \times 0.00066715\left(\mathrm{CH}_{4}\right.$ density in $\left.\mathrm{g} / \mathrm{ml}\right)$ (Chagunda et al., 2009)

\section{Methane from dry matter intake}

1. $\quad$ Methane $(\mathrm{l} / \mathrm{day})=0.0305 \mathrm{DMl}(\mathrm{g} / \mathrm{day})-4.441$ (Shibata et al., 1992$)$

2. $\quad M(\mathrm{~kg} / \mathrm{head} / \mathrm{day})=\mathrm{DMl} \times 0.0188+0.00158($ Howden \& Reyenga, 1987)

Analysis of variance was used to determine the effects of legume species and stage of growth and their interactions on biomass yield, CP, NDF, ADF, Ash, fat, and hemicellulose, using the general linear model's procedure of SAS (SAS, 2003). The analytical model was as follows:

$$
Y_{i j k}=\mu+F_{i}+S_{j}+(F S)_{i j}+e_{i j k}
$$


Where: $\mathrm{Y}_{\mathrm{ijkl}}=$ biomaas, $\mathrm{DM}$ yield, $\mathrm{CP}, \mathrm{CF}$, etc

$\mu=$ overall mean

$\mathrm{F}_{\mathrm{i}}=$ effect of type of forage $(\mathrm{j}=1,2$ Vigna, Lablab)

$\mathrm{S}_{\mathrm{j}}=$ effect of stage of growth ( $\mathrm{i}=$ pre-anthesis,anthesis, post-anthesis )

$(\mathrm{SF})_{\mathrm{ij}}=$ effect of interaction between stage of growth and forage type

$\mathrm{e}_{\mathrm{ijk}}=$ error term

Means were separated using Tukeys' studentized range test.

The effect of diet, sex and their interactions on methane production were analysed using the general linear model (PROC GLM) procedure of SAS (2003) and initial bodyweight was regarded as a covariate Methane was also measured over time, and data were analyzed using repeated measures of SPSS version 17. Tukeys' studentized range test was used to test the significant differences between means when F-test was found to be significant $(P<0.05)$. The statistical model used was:

$$
Y_{i j k l}=\mu+S_{i}+T_{j}+D_{k}+(S T)_{i j}+(S D)_{i k}+(T D)_{j k}+(S T D)_{i j k}+e_{i j k l}
$$

Where: $Y_{\mathrm{ijk}}$ is the dependent variable (methane emission)

$\mu$ is the overall mean

$S_{i}$ is the effect of sex of animal $(i=1,2)$

$\mathrm{T}_{\mathrm{j}} \mathrm{s}$ the effect treatment $(\mathrm{j}=1,2,3)$

$D_{k}$ is the effect of time in weeks $(k,=1,2,3,4,5,6)$

(ST)ijis the interaction effect between sex treatment

$(\mathrm{SD})_{\mathrm{ik}}$ is the interaction effect between sex and time

$(T D)_{j k}$ is the interaction effect between treatment and time

$(S T D)_{i j k}$ is three-way inteaction amoung sex treatment and time

$\mathrm{e}_{\mathrm{ijk} \mathrm{kl}}$ is the error term

\section{Results}

The proximate value of Lablab and Cowpea were evaluated, and the results are shown in Table 1.

Table 1 Proximate composition of Lablab and cowpea used in the study

\begin{tabular}{|c|c|c|c|c|c|c|c|c|}
\hline $\begin{array}{l}\text { Forage } \\
\text { species } \\
\text { (F) }\end{array}$ & $\begin{array}{l}\text { Stage of } \\
\text { Growth (S) }\end{array}$ & $\begin{array}{c}\text { Moisture } \\
\%\end{array}$ & $\begin{array}{c}\text { Ash } \\
\%\end{array}$ & $\begin{array}{l}\text { CP } \\
\%\end{array}$ & $\begin{array}{l}\text { Fat } \\
\%\end{array}$ & $\begin{array}{l}\text { ADF } \\
\%\end{array}$ & $\begin{array}{l}\text { NDF } \\
\%\end{array}$ & $\begin{array}{c}\text { Hemi- } \\
\text { celluloses } \\
\%\end{array}$ \\
\hline \multirow{4}{*}{$\begin{array}{l}\text { Labl } \\
a b\end{array}$} & $\begin{array}{l}\text { Pre- } \\
\text { anthesis }\end{array}$ & $7.58 \pm 1.65$ & $\begin{array}{c}12.67^{\mathrm{a}} \pm \\
0.22\end{array}$ & $\begin{array}{c}21.14^{\mathrm{a}} \pm \\
0.23\end{array}$ & $\begin{array}{c}3.00^{\mathrm{a}} \pm \\
0.12\end{array}$ & $\begin{array}{c}35.13^{\mathrm{C}} \pm \\
5.02\end{array}$ & $\begin{array}{c}48.7^{\mathrm{bc}} \pm \\
7.76\end{array}$ & $\begin{array}{c}13.61^{\mathrm{a}} \pm \\
1.78\end{array}$ \\
\hline & Anthesis & $7.47 \pm 1.65$ & $\begin{array}{c}11.00^{c} \pm \\
0.22\end{array}$ & $\begin{array}{c}17.73 b \pm \\
0.23\end{array}$ & $\begin{array}{c}2.37^{\mathrm{b}} \pm \\
0.12\end{array}$ & $\begin{array}{c}33.65^{\mathrm{c}} \pm \\
5.02\end{array}$ & $\begin{array}{c}46.51^{\mathrm{C}} \pm \\
7.76\end{array}$ & $\begin{array}{c}12.86^{\mathrm{a}} \pm \\
1.78\end{array}$ \\
\hline & $\begin{array}{l}\text { Post } \\
\text { anthesis }\end{array}$ & $7.44 \pm 1.65$ & $\begin{array}{c}10.67^{c} \pm \\
0.22\end{array}$ & $\begin{array}{c}17.51^{\mathrm{b}} \pm \\
0.23\end{array}$ & $\begin{array}{l}1.87^{\mathrm{c}} \pm \\
0.12\end{array}$ & $\begin{array}{c}39.87^{b} \pm \\
5.02\end{array}$ & $\begin{array}{c}52.61^{\mathrm{b}} \pm \\
7.76\end{array}$ & $\begin{array}{c}12.74^{\mathrm{ab}} \pm \\
1.78\end{array}$ \\
\hline & $\begin{array}{l}\text { Pre- } \\
\text { anthesis }\end{array}$ & $7.56 \pm 1.54$ & $\begin{array}{c}17.33^{\mathrm{b}} \pm \\
0.12\end{array}$ & $\begin{array}{c}24.88^{\mathrm{C}} \pm \\
0.23\end{array}$ & $\begin{array}{c}2.90^{\mathrm{b}} \pm \\
0.12\end{array}$ & $\begin{array}{c}38.36^{\mathrm{b}} \pm \\
5.02\end{array}$ & $\begin{array}{c}45.53^{\mathrm{C}} \pm \\
7.76\end{array}$ & $\begin{array}{c}7.16^{\mathrm{b}} \pm \\
1.78\end{array}$ \\
\hline \multirow[t]{2}{*}{$\begin{array}{l}\text { Vign } \\
\mathrm{a}\end{array}$} & Anthesis & $7.89 \pm 1.54$ & $\begin{array}{c}11.00^{c} \pm \\
0.12\end{array}$ & $\begin{array}{c}19.10^{d} \pm \\
0.23\end{array}$ & $\begin{array}{c}2.03^{\mathrm{b}} \pm \\
0.12\end{array}$ & $\begin{array}{c}30.4^{\mathrm{d}} \pm \\
5.02\end{array}$ & $\begin{array}{c}37.58^{\mathrm{d}} \pm \\
7.76\end{array}$ & $\begin{array}{c}7.18^{\mathrm{b}} \pm \\
1.78\end{array}$ \\
\hline & $\begin{array}{l}\text { Post } \\
\text { anthesis }\end{array}$ & $7.70 \pm 1.54$ & $\begin{array}{c}11.00^{\circ} \pm \\
0.12\end{array}$ & $\begin{array}{c}16.71^{\mathrm{b}} \pm \\
0.23\end{array}$ & $\begin{array}{c}1.33^{\mathrm{c}} \pm \\
0.12\end{array}$ & $\begin{array}{l}46.5^{\mathrm{a}} \pm \\
5.02\end{array}$ & $\begin{array}{c}57.63^{\mathrm{a}} \pm \\
7.76\end{array}$ & $\begin{array}{c}11.10^{\mathrm{ab}} \pm \\
1.78\end{array}$ \\
\hline \multirow{3}{*}{$\begin{array}{l}\text { Signi } \\
\text { fican } \\
\text { ce }\end{array}$} & $\mathrm{F}$ & 0.4337 & 0.001 & 0.001 & 0.002 & 0.002 & 0.027 & 0.022 \\
\hline & $S$ & 0.4337 & 0.001 & 0.001 & 0.021 & 0.020 & 0.023 & 0.031 \\
\hline & $F \times S$ & 0.323 & 0.153 & 0.398 & 0.236 & 0.001 & 0.024 & 0.661 \\
\hline
\end{tabular}

abcd Column means with different superscripts differ significantly at $P<0.05$, CP: crude protein, ADF: acid detergent fibre, NDF: neutral detergent fibre

The average moisture contents for cowpea and Lablab $(7.72 \%$ vs $7.50 \%)$ were similar $(P>0.05)$, irrespective of the stage of growth. Cowpea exhibited higher $(P<0.05)$ ash $(13.11 \%)$, ADF $(38.42 \%)$, and CP $(20.23 \%)$ than Lablab $(11.45 \%, 36.22 \%$, and $19 \%$, respectively). Lablab recorded significantly higher fat content $(2.41 \%)$ than cowpea $(2.09 \%)$. On average, cowpea recorded lower $(P<0.05)$ NDF values compared 
with Lablab (46.9\% vs $48.78 \%)$. There was a significant interaction between stage of growth and forage species for ADF, NDF, and hemicellulose content. Lablab showed higher $(P<0.05)$ NDF $(48.78 \%)$ and hemicelluloses $(13.07 \%)$ values than cowpea. Lablab showed higher $(P<0.05)$ ADF and NDF values post anthesis, a trend that was similar with cowpea. Furthermore, the NDF content increased $(P<0.05)$ post anthesis for both forages. Cowpea recorded a $6.33 \%, 8.17 \%$, and $8.14 \%$ decline in ash, CP, and ADF, respectively, from pre-anthesis to post anthesis. These percentages were significantly higher than those exhibited by Lablab of $2 \%, 3.63 \%, 4.74 \%$ for ash, CP and ADF, respectively. Three ANFs were evaluated for Lablab and cowpea, and the results are shown in Table 2.

Table 2 Anti-nutritional factors in Lablab and cowpea forage legumes used in the study

\begin{tabular}{|c|c|c|c|c|}
\hline $\begin{array}{l}\text { Forage } \\
\text { species }(F)\end{array}$ & Stage of growth (S) & $\begin{array}{c}\text { Tannins } \\
\text { (mgCAE/gDM) }\end{array}$ & $\begin{array}{c}\text { Phenolic } \\
\text { (mgGAE/gDM }\end{array}$ & Saponins \% \\
\hline & Pre-anthesis & $2.69^{c} \pm 0.047$ & $11.65^{d} \pm 0.06$ & $0.50^{\mathrm{b}} \pm 0.73$ \\
\hline \multirow[t]{3}{*}{ Vigna } & Anthesis & $1.24^{\mathrm{e}} \pm 0.047$ & $12.04^{c} \pm 0.06$ & $0.55^{b} \pm 0.73$ \\
\hline & Post-anthesis & $0.56^{\dagger} \pm 0.047$ & $4.52^{\mathrm{e}} \pm 0.06$ & $1.22^{b} \pm 0.73$ \\
\hline & Pre-anthesis & $3.31^{b} \pm 0.047$ & $15.41^{a} \pm 0.06$ & $2.53^{\mathrm{a}} \pm 0.73$ \\
\hline \multirow[t]{3}{*}{ Lablab } & Anthesis & $1.59^{d} \pm 0.047$ & $11.88^{\mathrm{cd}} \pm 0.06$ & $0.97^{b} \pm 0.73$ \\
\hline & Post-anthesis & $5.14^{\mathrm{a}} \pm 0.047$ & $13.14^{b} \pm 0.06$ & $1.16^{b} \pm 0.73$ \\
\hline & $F$ & 0.001 & 0.021 & 0.001 \\
\hline \multirow[t]{2}{*}{ Significance } & S & 0.003 & 0.001 & 0.023 \\
\hline & $F \times S$ & 0.033 & 0.022 & 0.041 \\
\hline
\end{tabular}

${ }^{\text {abcdet }}$ Means in a column with different superscripts are significant at $P<0.05$

The legume forage species and stage of growth influenced CT, phenolic and saponin levels significantly. Lablab exhibited a higher $(P<0.05)$ average tannin content compared with cowpea $(3.345 \pm$ $0.047 \mathrm{mg} \mathrm{CAE} / \mathrm{gDM}$ vs. $1.494 \pm 0.047 \mathrm{mg} \mathrm{CAE} / \mathrm{gDM}$ ). Lablab showed significantly higher average phenolic content (13.47 $\pm 0.0693 \mathrm{mg} \mathrm{GAE} / \mathrm{gDM})$ than cowpea (9.402 $\pm 0.0693 \mathrm{mg} \mathrm{GAE} / \mathrm{gDM})$. The tannin content of cowpea shows a general decline with stage of growth, while for Lablab there is a significant increase of $1.828 \pm 0.0693 \mathrm{mg} \mathrm{CAE} / \mathrm{gDM}$ from pre-anthesis to post anthesis. Both forages showed a general decline $(P$ $<0.05)$ in phenolic content with advancing stage of growth. Lablab exhibited the highest phenolic content in early stages of growth. The average saponin content was higher $(P<0.05)$ for Lablab than for cowpea. Lablab recorded the highest $(P<0.05)$ saponin content pre-anthesis, while cowpea had higher saponin levels post anthesis. There was a general increase with stage of growth for saponins in cowpea, yet Lablab showed a decline with advancing stage of growth $(P<0.05)$.

Chemical compositions of the three diets given to growing goats over a period of sixty days and the dietary inclusions are listed in Table 3. The three diets were formulated to provide the same amount of protein (iso-nitrogenous) and energy (iso-energetic). The control was a pellet diet, which had a CP level of $14 \%$ and ME of $8.87 \mathrm{Mj} / \mathrm{kg}$. The CP level was above the minimum requirement, as indicated by NRC (2007) of $12.6 \%$. The acid detergent lignin (ADL), acid detergent insoluble nitrogen (ADIN), and neutral detergent insoluble nitrogen (NDIN) compositions of treatment diets were also evaluated and the results are shown in Figure 1. Cowpea exhibited significantly higher ADL and NDIN contents compared with Lablab, which showed a significantly higher ADIN content. Enteric $\mathrm{CH}_{4}$ production figures are shown in Table 4 . Treatment diets had a significant effect on enteric $\mathrm{CH}_{4}$ when animals were ruminating $(P<0.05)$, but had no effect $(P$ $>0.05)$ when animals were standing or feeding. The control diet exhibited higher $(P<0.05) \mathrm{CH}_{4}$ emissions when animals were standing $(18.63 \pm 1.38 \mathrm{ppm}-\mathrm{m})$ and ruminating $(48.10 \pm 2.055 \mathrm{ppm}-\mathrm{m})$, while $\mathrm{T}_{1}$ showed the lowest $\mathrm{CH}_{4}$ emissions when animals were standing (15.92 $\left.\pm 1.38 \mathrm{ppm}-\mathrm{m}\right)$ and highest emissions when ruminating (46.86 $\pm 3.760 \mathrm{ppm}-\mathrm{m})$. 
Table 3 Chemical composition (\% for DM and \% DM for others) of Katambora hay supplemented with either Lablab or Cowpea and ewe pellets

\begin{tabular}{lccc}
\hline \multirow{2}{*}{ Nutrient } & Diet 1 & Diet 2 & Diet 3 \\
\cline { 2 - 4 } & Katambora/Vigna (1:4) & Pellets & Katambora/Lablab (1:4) \\
\hline DM\% & 92.3 & 89.92 & 92.72 \\
CP\% & 13.93 & 13.49 & 13.77 \\
CF\% & - & 23.51 & - \\
Fat\% & 2.17 & 5.92 & 1.97 \\
Me Mj/kg & 8.60 & 8.87 & 8.90 \\
NE Mcal/kg & - & 0.78 & - \\
NDF\% & 35.41 & 32.39 & 37.51
\end{tabular}

DM: dry matter; CP: crude protein; NDF: neutral detergent fibre; CF: crude fibre; Me: metabolizable energy; NE: net energy.

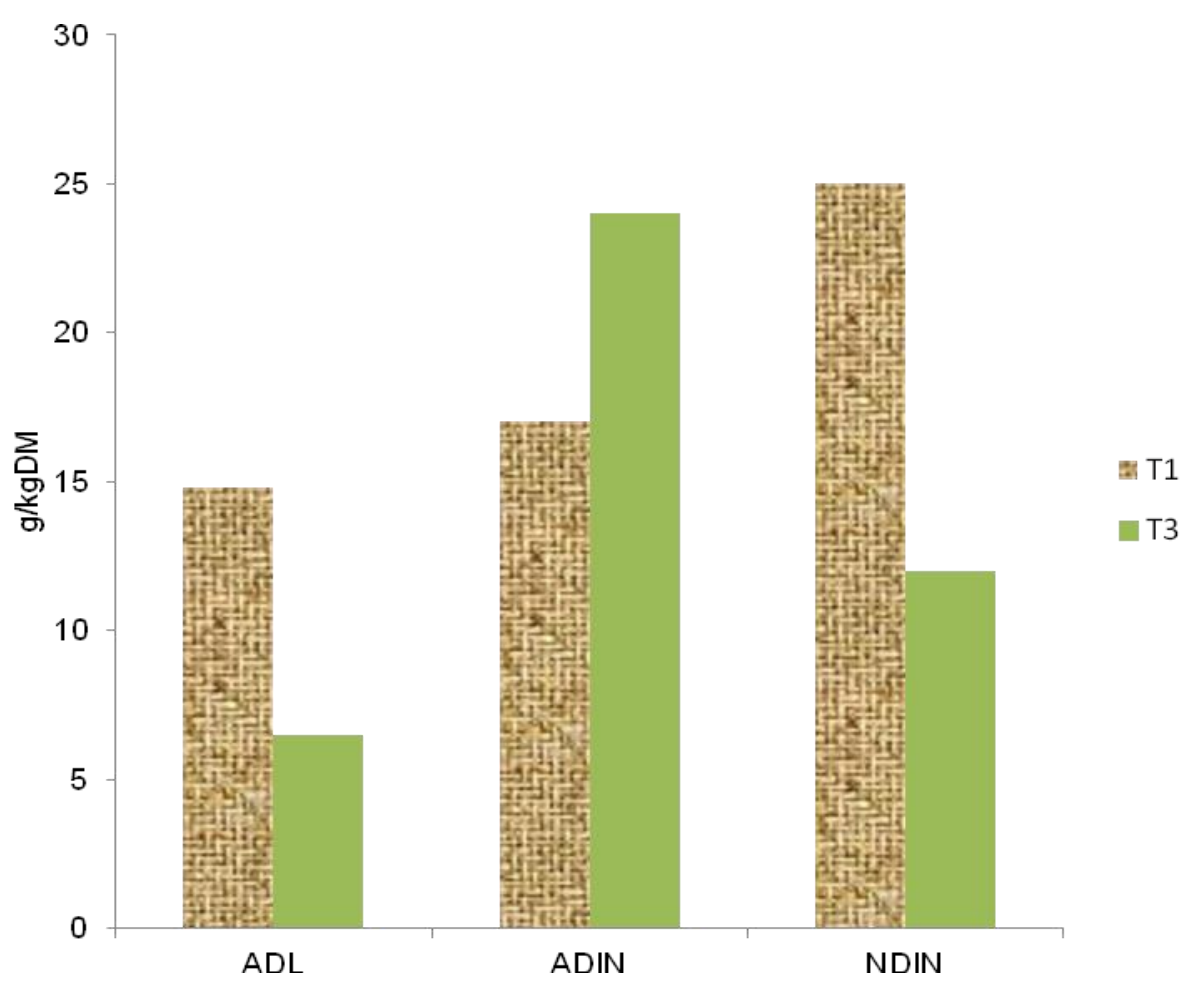

Key: $\quad A D L=$ acid detergent lignin; $A D I N=$ acid detergent insoluble nitrogen; NDIN neutral detergent insoluble nitrogen

Figure 1 Chemical composition of acid detergent lignin, acid detergent insoluble nitrogen and neutral detergent insoluble nitrogen for Katambora hay supplemented with either Lablab or Cowpea and ewe pellets.

Treatment three $\left(T_{3}\right)$ had significantly lower emissions when animals were ruminating $(35.28 \pm 3.64$ ppm-m) compared with $\mathrm{T}_{1}(46.86 \mathrm{ppm}-\mathrm{m})$ and $\mathrm{T}_{2}(48.10 \pm 2.97 \mathrm{ppm}-\mathrm{m})$. On average, animals in the control diet exhibited higher $(P<0.05) \mathrm{CH}_{4}$ emissions than in the other treatment diets: $35.62 \pm 0.0032 \mathrm{ppm}-\mathrm{m}, 34.89$ $\pm 0.0032 \mathrm{ppm}-\mathrm{m}$, and $31.04 \pm 0.0032 \mathrm{ppm}-\mathrm{m}$ for $\mathrm{T}_{2}, \mathrm{~T}_{1}$, and $\mathrm{T}_{3}$, respectively. The sex of animal and number of days (time in weeks) significantly affected $(P<0.05)$ enteric $\mathrm{CH}_{4}$ emissions. Male animals $(48.16 \pm 1.218$ $\mathrm{ppm}-\mathrm{m})$ produced higher methane emission than female animals $(33.57 \pm 1.218 \mathrm{ppm}-\mathrm{m})$. There was a wide 
significant difference in $\mathrm{CH}_{4}$ emissions between male and female animals in the control diet of $36.46 \pm$ $2.66 \mathrm{ppm}-\mathrm{m}$. This variation was significantly higher than other treatments, namely $17.5 \pm 2.66 \mathrm{ppm}-\mathrm{m}$ and $0.48 \pm 2.66 \mathrm{ppm}-\mathrm{m}$ for $\mathrm{T}_{1}$ and $\mathrm{T}_{3}$, respectively

Table 4 Least square means (ppm-m) of enteric methane emission from goats

\begin{tabular}{|c|c|c|c|c|c|c|c|c|}
\hline \multirow{2}{*}{ Activity } & \multicolumn{3}{|c|}{ Treatment $(\mathrm{T})$} & \multicolumn{3}{|c|}{$\operatorname{Sex}(S)$} & \multicolumn{2}{|c|}{$P$ values } \\
\hline & $\mathbf{T}_{1}$ & $\mathbf{T}_{2}$ & $\mathbf{T}_{3}$ & M & $\mathbf{F}$ & $\mathbf{T}$ & $\mathbf{S}$ & $\mathbf{T} \times \mathrm{S}$ \\
\hline Standing & $15.92 \pm 1.38$ & $18.63 \pm 1.38$ & $17.26 \pm 1.38$ & $17.90 \pm 1.21$ & $16.64 \pm 1.21$ & 0.47 & 0.001 & 0.300 \\
\hline Feeding & $41.89 \pm 2.66$ & $40.13 \pm 2.66$ & $40.59 \pm 2.66$ & $\begin{array}{c}48.16^{\mathrm{a}} \pm \\
1.21\end{array}$ & $\begin{array}{c}33.57^{\mathrm{b}} \pm \\
1.21\end{array}$ & 0.903 & 0.001 & 0.14 \\
\hline Ruminating & $\begin{array}{c}46.86^{\mathrm{ab}} \pm \\
3.64\end{array}$ & $\begin{array}{l}48.10^{\mathrm{a}} \pm \\
3.64\end{array}$ & $\begin{array}{c}35.28^{\mathrm{b}} \pm \\
3.64\end{array}$ & $46.48 \pm 1.21$ & $40.34 \pm 1.21$ & 0.028 & 0.148 & 0.001 \\
\hline
\end{tabular}

${ }^{\text {ab }}$ Row means with different superscript within treatments and sex, differ significantly at $P<0.05$

$\mathrm{T}_{1}: 71 \%$ Vigna hay, $19 \%$ Katambora hay, salt $(0.5 \%)$, molasses $(3 \%)$, maize $(5 \%)$ and mineral vitamin premix $(1.5 \%) ; \mathrm{T}_{2}$ $=90 \%$ lamb and ewe pellet plus $10 \%$ Katambora grass hay

$\mathrm{T}_{3}: 72 \%$ Lablab hay $19 \%$ Katambora hay, salt $(0.5 \%)$, molasses $(2 \%)$ maize $(5 \%)$ and mineral vitamin premix $(1.5 \%$.

Methane was also measured over time. The results are shown in Figure 2.

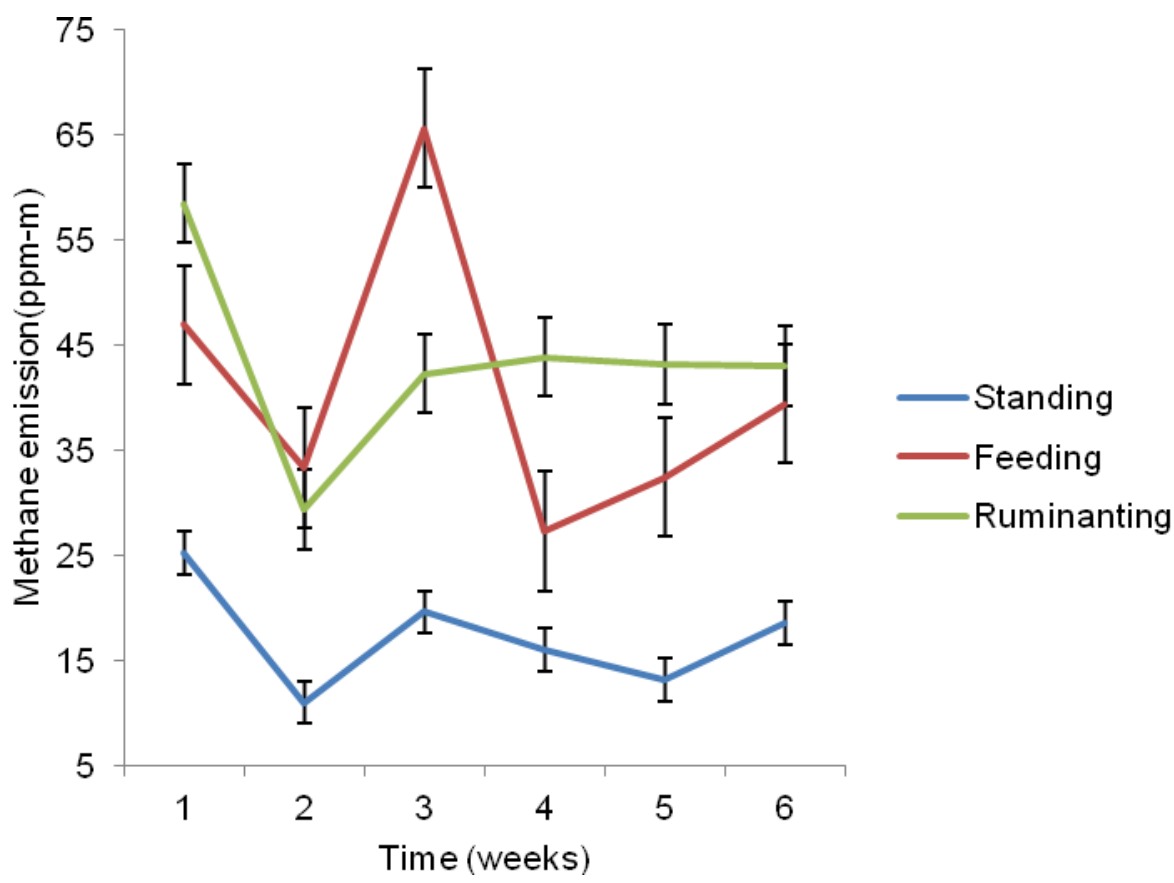

Figure 2 Methane emission of goats fed Lablab, Cowpea and ewe pellets

Methane production was not consistent $(P<0.05)$ with time, although there was a general decline for the measured activities: $6.66 \pm 1.38 \mathrm{ppm}-\mathrm{m}, 7.52 \pm 2.97 \mathrm{ppm}-\mathrm{m}$, and $15.42 \pm 3.64 \mathrm{ppm}-\mathrm{m}$ for standing, feeding, and ruminating, respectively, from week 1 to week 6 . Animals produced more $\mathrm{CH}_{4}$ with time during ruminating (43.39 $\pm 3.769 \mathrm{ppm}-\mathrm{m})$ than feeding $(40.86 \pm 5.673 \mathrm{ppm}-\mathrm{m})$ and standing $(17.27 \pm 2.055 \mathrm{ppm}-\mathrm{m})$. Generally, male animals emitted more $\mathrm{CH}_{4}$ than females, except for $\mathrm{T}_{1}$, in which females emitted more than males by $17.5 \pm 3.211 \mathrm{ppm}-\mathrm{m}$. Since LMD measures $\mathrm{CH}_{4}$ only in ppm-m, which are not equivalent to grams per $\mathrm{kg}$ or per day, $\mathrm{CH}_{4}$ can also be determined on a DMI basis to give an indication as to how much $\mathrm{CH}_{4}$ is produced by animals in friendly measurements (Table 5). These results show $\mathrm{CH}_{4}$ measurements within the last six days of the trial measured consecutively. Dry matter intake was positively correlated with $\mathrm{CH}_{4}$ 
production. Animals that consumed more feed produced significantly more $\mathrm{CH}_{4}$, as shown in Table 5 . Treatment diets and sex affected methane production significantly. $\mathrm{T}_{2}$ (control) had higher $(P<0.05) \mathrm{CH}_{4}$ emissions than $T_{1}$ and $T_{3}$. For all treatments animals produced significantly more gas when ruminating than feeding or just standing. $T_{1}$ exhibited significantly more gas than $T_{2}$ and $T_{3}$, namely $0.206 \pm 0.006 \mathrm{~g} /$ day, $0.2007 \pm 0.006 \mathrm{~g} /$ day, and $0.1685 \pm 0.006 \mathrm{~g} /$ day for $\mathrm{T}_{1}, \mathrm{~T}_{2}$, and $\mathrm{T}_{3}$, respectively $(P<0.05)$. On average, 4.602 $\pm 0.400 \mathrm{~kg} \mathrm{CH} 4,4.767 \mathrm{~kg} \pm 0.400 \mathrm{CH}_{4}$ and $4.719 \mathrm{k} \pm 0.400 \mathrm{~g} \mathrm{CH}_{4}$ is produced each year for $\mathrm{T}_{1}, \mathrm{~T}_{2}$, and $\mathrm{T}_{3}$ respectively. The control exhibited higher $(P<0.05) \mathrm{CH}_{4}$ emissions per $\mathrm{kg}$ of DMI. Sex significantly influenced the amount of gas produced, with male animals $(17.400 \pm 008 \mathrm{~L} /$ day; $12.46 \pm 0.008 \mathrm{~g} / \mathrm{kg} \mathrm{DMl} ; 0.126 \pm 0.008$ $\mathrm{g} /$ day) producing more $(P<0.05)$ gas than females $(15.47 \mathrm{~L} \pm 0.002 \mathrm{~L} /$ day; $12.28 \pm 0.002 \mathrm{~g} / \mathrm{kg} \mathrm{DMl} ; 0.0109 \pm$ $0.002 \mathrm{~g} /$ day). Sex and treatment diets both contributed significantly to $\mathrm{CH}_{4}$ emissions individually and interactively $(P<0.05)$.

Table 5 Least square means of methane emissions (Litres/day); (grams /kgDMI) and (grams/day)

\begin{tabular}{|c|c|c|c|c|c|c|c|c|}
\hline \multirow[t]{2}{*}{ Activity } & \multicolumn{2}{|c|}{ Treatment (T) } & \multicolumn{3}{|c|}{$\operatorname{Sex}(\mathrm{S})$} & \multicolumn{3}{|c|}{$P$ values } \\
\hline & $\mathrm{T}_{1}$ & $\mathbf{T}_{2}$ & $\mathbf{T}_{3}$ & M & $\mathbf{F}$ & $\mathbf{T}$ & $\mathbf{S}$ & $T \times S$ \\
\hline DMI (g) & $670.8^{c} \pm 4.61$ & $694.8^{a} \pm 4.61$ & $688.1^{b} \pm 4.61$ & $716.1^{a} \pm 3.76$ & $653^{b} .03 \pm 3.76$ & 0.001 & 0.001 & 0.0266 \\
\hline $\begin{array}{l}\text { 'Methane } \\
\text { (I/day) }\end{array}$ & $16.01^{c} \pm 0.006$ & $16.75^{a} \pm 0.006$ & $16.54^{b} \pm 0.006$ & $17.40^{a} \pm 0.008$ & $15.47^{b} \pm 0.02$ & 0.001 & 0.001 & 0.0001 \\
\hline $\begin{array}{l}{ }^{2} \text { Methane } \\
(\mathrm{g} / \mathrm{kg} \text { DMI) } \\
{ }^{3} \text { Methane (g/ }\end{array}$ & $\begin{array}{l}12.61^{\mathrm{C}} \pm 0.40 \\
\text { ay) }\end{array}$ & $13.06^{a} \pm 0.40$ & $12.93^{b} \pm 0.04$ & $12.46^{a} \pm 0.008$ & $12.28^{\mathrm{b}} \pm 0.02$ & 0.001 & 0.001 & 0.0001 \\
\hline Standing & $0.004^{a} \pm 0.48$ & $0.0037^{\mathrm{b}} \pm 0.48$ & $0.0035^{\mathrm{ab}} \pm 0.48$ & $0.595 \pm 0.28$ & $0.62 \pm 0.28$ & 0.031 & 0.720 & 0.1640 \\
\hline Feeding & $0.082^{a} \pm 0.005$ & $0.066^{a} \pm 0.005$ & $0.065^{a} \pm 0.005$ & $0083^{\mathrm{a}} \pm 0.06$ & $0.059^{b} \pm 0.06$ & 0.051 & 0.002 & 0.0001 \\
\hline Ruminating & $0.120^{a} \pm 0.008$ & $0.131^{\mathrm{b}} \pm 0.008$ & $0.100^{a} \pm 0.008$ & $0.126 \pm 0.006$ & $0.0109 \pm 0.006$ & 0.007 & 0.089 & 0.0001 \\
\hline
\end{tabular}

${ }^{\text {abc }}$ Row means with different superscript letters within treatments and sex differ significantly at $P<0.05$

$\mathrm{T}_{1}: 71 \%$ Vigna hay, $19 \%$ Katambora hay, salt $(0.5 \%)$, molasses $(3 \%)$, maize $(5 \%)$ and mineral-vitamin premix $(1.5 \%) ; \mathrm{T}_{2}$ : $90 \%$ lamb and ewe pellet plus 10\% Katambora grass hay; $\mathrm{T}_{3}: 72 \%$ Lablab hay $19 \%$ Katambora hay, salt $(0.5 \%)$, molasses $(2 \%)$ maize $(5 \%)$ and mineral-vitamin premix $(1.5 \%)$

${ }^{1}$ Methane calculated according to Shibata et al. (1992)

${ }^{2}$ Methane calculated according to Howden \& Reyenga (1987)

${ }^{3}$ Methane calculated according to Chagunda et al. (2009)

\section{Discussion}

The voluntary intake of feed and the extent to which the quantity of DM consumed supplies energy, proteins, minerals and vitamins to the animal determines its nutritive value. The DM contents of cowpea and Lablab were similar, and the current results were similar to those obtained by Ayan et al. (2012) and Ayana et al. (2013). Forage legumes generally have a CP range of $14-20 \%$, as indicated by Norton \& Poppy (1995), Kalamani \& Gomez (2001), and Mahala et al. (2012). The results from this study confirm earlier observations for Lablab and cowpea. However, cowpea had higher ash, CP, and ADF content than Lablab. This was expected because cowpea exhibited indeterminate (continuous growth after florescence) nature of growth. On the other hand, Lablab had higher fat and NDF content and these are known to reduce feed intake. However, a high NDF content is indicative of higher forage degradability (Mahala et al., 2012; Waters et al., 2013). The high ADF values for cowpea indicate that it is not easily digestible and or degradable. This is because ADF is composed principally of cellulose and lignin, which are not easily degradable. A report by Meale et al. (2012) showed that the higher the fibre content of a diet, the lower the DMI and fermentability, and the higher the residence time, and gas production.

The results show a general increase in NDF and ADF with advancing stage of maturity. Jingura et al. (2001) and Mahala et al. (2012) also confirmed these findings. Legume forages accumulate carbohydrates as the plant matures. This is in line with what was concluded earlier by Mupangwa (2000). The effects of this silication and lignification translate into low degradability values within the rumen. This can be preferred if the animal has enough rumen degradable protein in the diet. The NDF content of legume forages has been the major drawback to their full utilization in animal nutrition. Legumes lack enough fibre to optimize rumen functionality, hence the requirement that they should be used as supplements to grass forages (Jingura et 
al., 2001; Tibayungwa et al., 2010). The low values of ADF recorded with Lablab makes it a legume of choice since high ADF values limit rumen microbial protein synthesis (Ayan et al., 2012). Although tropical browse species and forage legumes are used as animal feed, they contain substantial amounts of anti-nutrients, including phenolic compounds, tannins, saponins and other secondary compounds (Makkar, 2003). Phenols are the largest category of phytochemicals and are widely distributed in the plant kingdom. These are generally divided into three important groups: flavonoids, phenolic acids, and polyphenols. They show a diversity of biological activities (Silva et al., 2007), thereby influencing digestibility of forages. The results from the current study indicated that total phenols fall within a range that does not influence digestibility (Makkar, 2003; Abarghuei et al., 2014).

There are two forms of tannins in the plant kingdom: hydrolysable tannins (HTs) and condensed tannins (CTs). The existence of tannin in plants has the potential to reduce the nutritional value of forages. Tannins, in particular, are known to bind feed proteins, making them unavailable for rumen microbial degradation (Mueller-Harvey, 2005), thereby limiting rumen microbial protein synthesis, which is important in ruminant digestive physiology. A report by Mueller-Harvey (2005) indicated that HTs are generally harmful, in comparison with CTs, which are considered safe if they account for less than $5 \%$ of DM in the feed. Min et al. (2003) also reported that forages containing more than $50 \mathrm{~g} \mathrm{CT} / \mathrm{kg}$ DM have limited palatability, voluntary intake, digestibility and N retention. However, Goel \& Makkar, (2012) reported that low dietary tannin levels improve nitrogen utilization by ruminants. This is possible because tannins have the capability to alter the site of protein digestion from the rumen to the intestines, hence improving amino acid absorption. In the language of ruminant digestive physiology, this is referred to as rumen escape protein and is purported to lead to higher growth rates, milk yield, and fertility (Mueller-Harvey, 2005). Tannins have also been shown to reduce enteric $\mathrm{CH}_{4}$ production in ruminants (Makkar 2003; Tavendale et al., 2005; Carulla et al., 2005 Hess et al., 2011), promote high digestibility of nutrients (Yisehak et al., 2014), and decrease the number of cellulolytic bacteria (McSweeny et al., 2001). In addition, they are resistant to enzymatic digestion (Goel \& Makkar, 2012), shift short-chain fatty acid (SCFA) production, and reduce DMD and OMD (Hess et al., 2006; Abdalla et al., 2007; Animut et al., 2008; Tiemann et al., 2008). In the current study, Lablab showed higher CTs levels than cowpea. However, these results still fall below $50 \mathrm{gCT} / \mathrm{kgDM}$, as reported to have negative effects on ruminants (Makkar, 2003). Thus, tannin levels influenced DM and OMD in the current study.

Saponins are natural detergents, high molecular weight glycosides in which sugars are linked to a triterpene or steroidal aglycone moiety (Goel \& Makkar, 2012). Plants rich in saponins enhance the flow of microbial protein from the rumen, as reported by Das et al. (2012), increase the efficiency of feed utilization (Jayanegara et al., 2012), decrease protozoal populations (Das et al., 2012), and consequently reduce $\mathrm{CH}_{4}$ production (Goel \& Makkar, 2012). Reduction in $\mathrm{CH}_{4}$ production is achieved by increasing propionate production and decreasing protozoal numbers (Hess et al., 2006). Higher DM and OM digestibility coefficiencies have been reported in sheep supplemented with a saponin content of between $2 \%$ and $4 \%$ (Das et al., 2012; Jayanegara et al., 2012; Lu \& Jorgensen, 1987). However, Azami et al. (2013) reported no changes in OM or DM digestibility at the same level of saponin inclusions. In the present study, the saponin content differs with the stage of growth and generally fall below the $2 \%$ minimum level expected to influence digestibility. Tannins and saponins have been reported to lower digestibility of nutrients. However, the level at which they achieve this is still unknown (Norrapoke et al., 2012; Wanapat et al., 2015). Coulman et al. (2000) suggested that forages have lower fibre content, higher DMI, and faster rate of passage through the rumen; hence, they have the capacity to reduce enteric $\mathrm{CH}_{4}$ production. This was confirmed by Beauchemin et al. (2009) and Archime' de et al. (2011).

The contribution of ruminant livestock production systems to global anthropogenic $\mathrm{CH}_{4}$ emissions has long been hypothesized. According to Steinfeld (2006), 50\% or more of GHG emissions come from enteric fermentation. Nevertheless, Scholtz et al. (2013) dispute this and argue that only $5 \%$ of total global $\mathrm{CH}_{4}$ is enteric. This enteric production is a loss in dietary energy, as has been extensively researched and reviewed by Eckard et al. (2010), Morgavi et al. (2010), and Cottle et al. (2011). Methane production in the tropics exhibits great variations and is governed by such animal factors as weight, age, species, and breed, together with feed characteristics (Brouček, 2014). According to Ramin \& Huhtanen (2013), Lovett et al. (2005), and Du Toit et al. (2013), DMI is one of the main determinants of total $\mathrm{CH}_{4}$ production. These authors also observed that gross energy intake is negatively related to $\mathrm{CH}_{4}$ production, and positively correlated with diet digestibility. On the other hand, Scholtz et al. (2013) concluded that the production system is the major determinant factor in the total amount of $\mathrm{CH}_{4}$ produced. They cited that animals on rangelands would produce more $\mathrm{CH}_{4}$ gas than those on intensive systems, particularly feedlots. Results from this study confirmed that DMI has a significant bearing on $\mathrm{CH}_{4}$ emissions. As animals consumed more, they produced significantly more gas compared with their contemporaries. In the current study, growing goats produced between 12 to $13 \mathrm{~g} / \mathrm{kg} \mathrm{DM}$ of $\mathrm{CH}_{4}$. This is considered lower when compared with results obtained by Du Toit et al. (2013). This was the effect of forage legumes on $\mathrm{CH}_{4}$ production. Woodward et al. (2004) indicated that 
forage legumes can be used to influence rumen characteristics significantly to achieve reduced $\mathrm{CH}_{4}$ emissions. According to Waghorn \& Clark (2004) and Peters et al. (2013), tropical forage species have the capability of reducing ruminant $\mathrm{CH}_{4}$ emissions per unit livestock product compared with lower-quality rangeland species. This is because they contain less structural carbohydrates and more CTs than grass. Results from this study also showed that goats produce between 16 and 17 litres $\mathrm{CH}_{4}$ per day. These results are similar to those proposed by Du Toit et al. (2013) for animals in the Eastern Cape of South Africa.

From a practical point of view, animal enteric $\mathrm{CH}_{4}$ production is relative to activities by the animal. Results show that ruminating animals produce more gas than feeding or idle animals. This was confirmed earlier by Chagunda et al. (2009). Although the animal appears quiet and relaxed during rumination, the activities and process in its digestive system dominate enteric $\mathrm{CH}_{4}$ production compared with any other activities that a ruminant animal would perform per its daytime budget. This was reported earlier by Marik \& Levin (1996). The ruminant digestive tract is a reservoir of microorganisms that are beneficial to the host animal. Among these microorganisms, found is a group called methanogens. These methanogens produce $\mathrm{CH}_{4}$ by a process called methanogenesis or biomethanation as a by-product of anaerobic fermentation. This process represents an inefficient utilization of feed (Chagunda et al., 2009). The process of methanogenesis is a two-stage process. First, glucose equivalents are hydrolysed to yield pyruvate. This hydrolysis is achieved by extracellular microbial enzymes in the presence of protozoa and fungi. Also, pyruvate undergoes oxidation reactions under anaerobic conditions to produce reduced co-factors like nicotinamide adenine dinucleotide hydrogen $(\mathrm{NADH})$. This reduced co-factor, for example, is then re-oxidized to nicotinamide adenine dinucleotide (NAD) to complete the synthesis of VFAs. In essence, these two processes are crucial to VFA syntheses and therefore are inevitable for ruminants. Ruminants use VFAs as a source of energy since all the dietary glucose is quickly used up by symbiotic microorganisms for their own microbial protein synthesis. The production of VFAs from pyruvate releases free hydrogen $\left(\mathrm{H}_{2}\right)$, which, if left unchecked, results in lower $\mathrm{pH}$, which might culminate in metabolic conditions such as acidosis or rumen stasis. The ruminant system has a way of dealing with excess $\mathrm{H}_{2}$. This is where methanogens become handy to achieve homeostasis. Methanogens eliminate the available $\mathrm{H}_{2}$ by using $\mathrm{CO}_{2}$ to produce $\mathrm{CH}_{4}$ (Kebreab et al., 2006a).

Bell \& Eckard (2012), however, observed that elimination of enteric $\mathrm{CH}_{4}$ has consequences as it could result in a reduction in rumen fermentation rate or in a shift in VFA production. They also observed that there is an inverse relationship between $\mathrm{CH}_{4}$ production and the presence of propionate (Bell \& Eckard, 2012). In its simplest form, propionate is deemed a hydrogen sink. This means it reduces the amount of $\mathrm{H}_{2}$ available for methanogens, hence reduces the amount of $\mathrm{CH}_{4}$ produced. The three main VFAs are generally produced in relation to each other at a ratio of 70: 20: 10 for acetate: propionate: butyrate. However, these proportions can be manipulated by dietary intervention to reduce the ratio of acetate to propionate in particular to less than 0.5 (Bell \& Eckard, 2012). Any ratios above this margin result in excess $\mathrm{H}_{2}$, which becomes available to form $\mathrm{CH}_{4}$ (a function of methanogens). However, if the $\mathrm{H}_{2}$ produced is not used correctly, ethanol or lactate can form. These inhibit microbial growth, forage digestion, and any further production of VFAs. Enteric $\mathrm{CH}_{4}$ production is reduced if the flow of $\mathrm{H}_{2}$ shifts towards alternative electron acceptors. Unfortunately, many of the alternative acceptors are less thermodynamically favourable; therefore, $\mathrm{CO}_{2}$ becomes reduced to $\mathrm{CH}_{4}$. From a dietary perspective, the $\mathrm{CH}_{4}$ reduction is achieved by diluting starch (a major source of glucose) with a non-forage carbohydrate source that is less rapidly fermented, produces more propionate, without reducing ruminal $\mathrm{pH}$. Forage legumes are known to possess such characteristics hence have been proposed to reduce $\mathrm{CH}_{4}$ production (Coulman et al., 2000; Peters et al., 2013). However, Grainger \& Beauchemin (2011) suggested that forage-based diets generally result in higher $\mathrm{CH}_{4}$ emissions than mixed or concentrate-based diets. This was also alluded to by Scholtz et al. (2013). This is contrary to results from this study, which have shown that legume forage-based diets reduce $\mathrm{CH}_{4}$ production significantly compared with a pellet-based diet. The reason is that in this study $\mathrm{CH}_{4}$ was not measured per kilogram of weight gain of goats. Sanchis (2015) observed $\mathrm{CH}_{4}$ emissions ranging between 19.6 to $29.7 \mathrm{~g} /$ day with Murciano-Granadina goats. The result from this study shows an even lower range of $\mathrm{CH}_{4}$ emissions. This confirms the earlier proposals by Moss et al. (2000), Steinfeld et al. (2006) and Storm et al. (2012) that dietary manipulations subdue methanogenesis.

\section{Conclusion}

Legume forages (Vigna unguiculata and Lablab purpureus) reduced enteric methane production significantly from goats. This was achieved by the level of tannins in these forages and lower fibre content. Methane production is relative to animal activity with ruminating animals producing more gas compared with feeding or standing. The sex of the animal also affected methane production significantly, with male animals producing more gas than females. Enteric methane production is positively related to DMI. 


\section{Acknowledgements}

This research was supported financially by the GMRDC- RTF 150416117267.

\section{Authors' Contributions}

SW worked on the original report and data analysis, JM conceptualised the paper and VM worked on the study design execution and manuscript preparation.

\section{Conflict of interest Declaration}

There is no conflict of interest associated with this manuscript.

\section{References}

Azami, M.H., Tahmasbi, A.M., Ghaffari, M.H., Naserian, A.A., Valizadeh, R. \& Ghaffari, A.H., 2013. Effects of saponins on rumen fermentation, nutrient digestibility, performance, and plasma metabolites in sheep and goat kids. Annu Res. Rev. Biol. 3, 596-607.

Abarghuei, M.J., Rouzbehan, Y. \& Salem, A.F., 2014.The influence of pomegranate peel extracts on in vitro gas production kinetics of rumen inoculum of sheep. Turk. J. Vet. Anim. Sci. 38, 212-219.

Abdalla, A.L., Godoy, P.B., Longo C., Araujo Neto, J.C., Peçanha, M.R.S.R., Bueno, I.C.S., Vitti, D.M.S.S. \& Sallam, S.M.A., 2007. Methane emission, protozoa and methanogen counts in sheep fed coconut oil of a Brazilian tanninrich plant (Mimosa casealpineaefolia). Microb. Ecol. Health Dis. 19, 33.

AFRC. 1993. Energy and protein requirements of ruminants. Agricultural and Food Research Council. CAB International, Wallingford, UK. 5-55.

Animut, G., Puchala, R., Goetsch, A.L., Patra, A.K., Sahlu, T., Varel, V.H. \& Wells, J., 2008. Methane emission by goats consuming diets with different levels of condensed tannins from Lespedeza. Anim. Feed Sci.Tech.144, $212-227$.

AOAC. 2005. Official methods of analysis. Association of Official Analytical Chemists. 18th edition. Virginia, USA.

Archimède, H., Eugène, M., Marie Magdeleine, C., Boval, M., Martin, C., Morgavi, D.P., Lecomte, P. \& Doreau, M., 2011. Comparison of methane production between C3 and C4 grasses and legumes. Anim. Feed Sci. and Tech. 166, 59-64.

Ayan, I., Mut, H., Basaran, U., Acar, Z. \& Asci, O.O., 2012. Forage potential of cowpea (Vigna unguiculata L. Walp). Turk. J. Field Crops. 17, 135-138.

Ayana, E.E., Mengistu, T.A. \& Hassen, A., 2013. Advanced evaluation of cowpea (Vigna unguiculata) accessions for fodder production in the Central Rift Valley of Ethiopia. J. Agri. Ext. Rural Dev. 5, 55-61.

Beauchemin, K.A., McAllister, T.A. \& McGinn, S.M., 2009. Dietary mitigation of enteric methane from cattle. CAB Reviews: Perspectives in Agriculture, Veterinary Science, Nutri. and Nat. Res. 4,118.

Bell M.J. \& Eckard, R.J., 2012. Reducing enteric methane losses from ruminant livestock - its measurement, prediction and the influence of diet. Khalid Javed (ed.), InTech. Available at https://www.intechopen.com/books/livestockproduction/reducing-enteric-methane-losses-from-ruminant-livestock-its-measurement-prediction-and-theinfluence.Doi.org/10.5772/50394.

Brouček J., 2014. Methods of methane measurement in ruminants. Slovakian J. Anim. Sci. 47, 51-60.

Carulla, J.E., Kreuzer, M., Machmuller, A. \& Hess, H.D., 2005. Supplementation of Acacia mearnsii tannins decreases methanogenesis and urinary nitrogen in forage-fed sheep. Aust. J. Agric. Res. 56, 961-970.

Chagunda, M.G.G., Ross D. \& Roberts, D.J., 2009. On the use of a laser methane detector in dairy cows. Comp. Elect. Agric. 68, 157-160.

Chilonda, P. \& Otte, J., 2006. Indicators to monitor trends in livestock production at national, regional and international levels. Livestock Research for Rural Development. Volume 18, Article \#117. Retrieved January 24, 2018, from http://www.Irrd.org//rrd18/8/chil18117.htm

Cottle, D.J, Nolan, J.V. \& Wiedemann, S.G., 2011. Ruminant enteric methane mitigation: A review. Anim. Prod. Sci. 51, 491-514.

Coulman, B., Goplen, B., Majak, W., McAllister, T., Cheng, K.J., Berg, B., Hall, J., McCartney, D. \& Acharya, S., 2000. A review of the development of a bloat-reduced alfalfa cultivar. Can. J. Plant Sci. 80, 74-91

Das, T.K., Banerjee, D., Chakraborty. D., Pakhira, M.C., Shrivastava, B. \& Kuhad, R.C., 2012. Saponin: Role in animal system. Vet. World 5, 248-254.

Du Toit, C.J.L., Van Niekerk, W.A. \& Meissner, H.H., 2013. Direct greenhouse gas emissions of the South African small stock sectors. S. A. J. Anim. Sci. 43,340-361.

Eckard, R.J., Grainger, C. \& de Klein, C.A.M., 2010. Options for the abatement of methane and nitrous oxide from ruminant production: A review. Livest. Sci. 130, 47-56.

Goel, G. \& Makkar, H.P.S., 2012. Methane mitigation from ruminants using tannins and saponins. Trop. Anim. Health Prod. 44, 729-739.

Goering, H.K. \& Van Soest, P.J., 1970. Forage fibre analysis. Agricultural handbook. ARS, USA. 1-20.

Grainger, C. \& Beauchemin, K.A., 2011. Can enteric methane emissions from ruminants be lowered without lowering their production? Anim. Feed. Sci. Technol. 166 -167, 308-320.

Hess, H.D., Tiemann, T.T., Noto, F., Carulla, J.E. \& Kreuzer, M., 2006. Strategic use of tannins as means to limit methane emission from ruminant livestock. International Congress Series 1293, 164-167.

Hess, M., Sczyrba, A., Egan, R., Kim, T.W., Chokhawala, H., Schroth, G., Luo, S., Clark, D.S., Chen, F., Zhang, T., Mackie, R.I., Pennacchio, L.A., Tringe, S.G., Visel, A., Woyke, T., Wang, Z. \& Rubin, E.M., 2011. Metagenomic discovery of biomass-degrading genes and genomes from cow rumen. Sci. 331, 463-467. 
Howden, S.M. \& Reyenga, P.J., 1987. Methane emissions from Australian livestock: Implications of the Kyoto protocol. Aust. J. Agric. Res. 50, 1285-1291.

Jayanegara, A., Leiber, F. \& Kreuzer, M., 2012. Meta-analysis of the relationship between dietary tannin level and methane formation in ruminants from in vivo and in vitro experiments. J. Anim. Physiol. Anim. Nut. Doi: 10.1111/j.1439-0396.2011.01172.

Jingura, R.M., Sibanda, S. \& Hamudikuwanda, H., 2001. Yield and nutritive value of tropical forage legumes grown in semi-arid parts of Zimbabwe. Tropi. Grass. 35, 168-174.

Kalamani, A.S. \& Gomez, M.S., 2001. Genetic variability in Clitoria spp. Ann. Agr. Re. 22, 243-245.

Kebreab, E., Clark, K., Wagner-Riddle. C. \& France, J., 2006a. Methane and nitrous oxide emissions from Canadian animal agriculture: A review. Can. J. Anim. Sci. 86,135-158.

Lovett, D.K., Stack, L.J., Lovell, S., Callan, J., Flynn, B., Hawkins, M. \& O'Mara, F.P., 2005. Manipulating enteric methane emissions and animal performance of late lactation dairy cows through concentrate supplementation at pasture. J. Dairy Sci. 88, 2836-2842.

Lu, C.D. \& Jorgensen, A.A., 1987. Alfalfa saponins affect site and extent of nutrient digestion in ruminants. J. Nutr. 117, 919-927.

Mahala A.G., Amasiab, S.O., Yousif, M.A. \& Elsadig, A., 2012. Effect of plant age on DM yield and nutritive value of some leguminous plants (Cyamopsis tetragonoloba, Lablab purpureus and Clitoria (Clitoria ternatea)). Int. Res. J. Agri. Sci. Soil Sci. 2, 502-508.

Makkar, H.P.S., 2003. Effects and fate tannins in ruminant animals, adaptation to tannins, and strategies to overcome detrimental effects of feeding tannin-rich feeds. Small Rumin. Res. 49, 241- 256.

Mapiye, C., Foti, R., Chikumba, N., Poshiwa, X., Mwale, M., Chivuraise, C. \& Mupangwa, J.F., 2007. Constraints to adoption of forage and browse legumes by smallholder dairy farmers in Zimbabwe. Liv. Res. Rural Dev. 18, 12.

Marik, T. \& Levin, I., 1996. A new tracer experiment to estimate the methane emissions from a dairy cow shed using sulfur hexafluoride (SF6). Global Biog. Cyc. 10, 413-418.

McDonald, P., Greenhalgh, J.F.D., Morgan, C.A., Edwards, R., Sinclair, L. \& Wilkinson, R., 2011. Animal nutrition. 7th edition. Benjamin Cummings, Harlow, Essex.

McSweeney, C.S., Palmer, B., McNeill, D.M. \& Krause, D.O., 2001. Microbial interaction with tannins: Nutritional consequences for ruminants. Anim. Feed Sci. Technol. 91, 83-93.

Meale, S.J., Mcallister, T.A., Beauchemin, K.A., Harstard, O.M. \& Chaves, A.V., 2012. Strategies to reduce greenhouse gases from ruminant livestock. Acta Agriculturae Scandinavica Anim. Sci. 62, 199-211.

Meissner, H.H., Scholtz, M.M. \& Palmer, A.R., 2013. Sustainability of the South African livestock sector towards 2050. Part 1: Worth and impact of the sector. S. Afr. J. Anim. Sci. 43, 282-297

Min, B.R., Barry, T.N., Attwood, G.T. \& McNabb, W.C., 2003. The effect of condensed tannins on the nutritional and health of ruminants fed fresh temperate forage: A review. Anim. Feed Sci. Technol. 106, 3-19.

Morgavi, D.P., Martin C. \& Moreau, D., 2010. Methane mitigation in ruminants: from microbe to the farm scale. Animal 4, 351-365

Moss A.R., Jouany, J.P. \& Newbold, J., 2000. Methane production by ruminants: Its contribution to global warming. Ann. Zootech. 49, 231-253.

Mucina, L. \& Rutherford, M.C., 2006. The vegetation of South Africa, Lesotho and Swaziland. Strelitizia19. South African National Biodiversity Institute, Pretoria, South Africa. (808 pp with CD GIS database).

Mueller-Harvey, I., 2005. Tannins in animal health and nutrition - opportunities for temperate and tropical regions. In: M.R.P. Wanapat (ed.). Proceedings of International Symposium on Integrating Livestock-Crop Systems to Meet the Challenges of Globalisation. Khon Kaen, Thailand. pp. 448-450.

Mupangwa, J.F., 2000. Nutritive value, intake and utilisation of forage legumes in ruminants. Ph.D. thesis. University of Zimbabwe.

Norrapoke, T., Wanapat, M. \& Wanapat, S., 2012. Effects of protein level and mangosteen peel pellets (mago-pel) in concentrate diets on rumen fermentation and milk production in lactating dairy crossbreds. Asian-Austr. J. Anim. Sci. 25, 971-979.

Norton, B.V. \& Poppy, D.P., 1995. Composition and nutritional attributes of pasture legumes. In: J.P.F. D'Mello \& C. Devendra (eds). Tropical legumes in animal nutrition. CABI, Wallingford, UK. 23-47.

NRC (National Research Council), 2001. Nutrient requirements of small ruminants. National Academy Press, Washington DC, USA.

Omoruyi, B.E., Bradley, G. \& Afolayan, A.J., 2012. Antioxidant and phytochemical properties of Carpobrotus edulis (L.) bolus leaf used for the management of common infections in HIV/AIDS patients in Eastern Cape Province. BMC Complementary and Alternative Medicine 12, 3-9.

Peters, M., Rao, I., Fisher, M., Subbarao, G., Martens, S., Herrero, M., van der Hoek, R., Schultze-Kraft, R., Miles, J., Castro, A., Graefe, S., Tiemann, T., Ayarza, M. \& Hyman, G., 2013. Tropical forage-based systems to mitigate greenhouse gas emissions. In: Hershey $\mathrm{CH}$; Neate $\mathrm{P}$, eds. Eco-Efficiency: From vision to reality. CIAT (Centro Internacional de Agricultura Tropical), Cali, Colombia. p. 171-190

Ramin, M. \& Huhtanen, P., 2013. Development of equations for predicting methane emissions from ruminants. J. Dairy Sci. 96, 2476-2493.

Samatha, T., Shyamsundarachary, R., Srinivas, P. \& Swamy, N.R. 2012. Quantification of total phenolic and total flavonoid contents in extracts of Oroxylum Indicum L. Kurz. Asian J. Pharm. Clin. Res. 5, 177-179.

Sanchis, C.I., 2015. Influence of nutrition on methane gas production in Murciano-Granadina goats. PhD thesis, Universitat Politècnica de València, Valencia, Spain. 77-79.

SAS 2003. SAS for Windows, Release 9.1 SAS Institute, Cary, NC, USA. 
Scholtz, M.M., Van Ryssen, J.B.J., Meissner, H.H.\& Laker, M.C., 2013. A South African perspective on livestock production in relation to greenhouse gases and water usage. S. Afr. J. Anim. Sci., 43, 248-254.

Scholtz, M.M., Maiwashe, A., Neser, F.W.C., Theunissen, A., Olivier, W.J., Mokolobate, M.C. \& Hendriks, J., 2013. Livestock breeding for sustainability to mitigate global warming, with the emphasis on developing countries. S. Afr. J. Anim. Sci. 43, 269-281

Shibata, M., Terada, F., Iwasaki, K., Kurihara, I. \& Nishida, T., 1992. Methane production in heifers, sheep and goats consuming diets of various hay concentrate ratio. Anim. Sci. Technol. 64, 790-796.

Silva, E.M., Souza, J.N.S., Rogez, H., Rees, J.F. \& Larondelle, Y., 2007. Antioxidant activities and polyphenolic contents of fifteen selected plant species from the Amazonian region. Food Chem.101, 1012-18.

Soil Classification Working Group (SCWG). 1991. Soil classification: A taxonomic system for South Africa. Memoirs on the Agricultural Natural Resources of South Africa No 15. Department of Agricultural Development, Pretoria, South Africa.

SPSS Base 17.0 SPSS Software Products, Marketing Department, SPSS Inc. Chicago. IL. USA.

Steinfeld, H., Gerber, P., Wassenaar, T., Castel, V., Rosales, M. \& de Haan, C., 2006. Livestock's long shadow Environmental issues and options. FAO report, Rome, Italy. 1-6.

Storm, I.M.L.D., Hellwing, A.L.F., Nielsen, N.I. \& Madsen, J., 2012. Methods for measuring and estimating methane emission from ruminants. Animal 2, 160-183.

Sun, B., Ricardo-da-Silva, J.M. \& Spranger, I., 1998. Critical factors of vanillin assay for catechins and proanthocyanidins. J. Agric. Food Chem. 46, 4267-4274.

Tavendale, M.H., Meagher, L.P., Pacheco, D., Walker, N., Attwood, G.T. \& Sivakumaran, S., 2005. Methane production from in vitro rumen incubations with Lotus pedunculatus and Medicago sativa, and effects of extractable condensed tannin fractions on methanogenesis. Anim. Feed Sci. Technol. 123-124, 403-419.

Tibayungwa. F.J., Mugisha, Y.T. \& Nabasirye, M., 2010.Modelling the effect of supplementing elephant grass with lablab and desmodium on weight gain of dairy heifers under stall-feeding system. Afr. J. Agric. Res. 6, 3232-3239.

Tiemann, T.T., Lascano, C.E., Wettstein, H-R., Mayer, A.C., Kreuzer, M. \& Hess, H.D., 2008. Effect of the tropical tanninrich shrub legumes Calliandra calothyrsus and Flemingia macrophylla on methane emission and nitrogen and energy balance in growing lambs. Animal 2, 790-799.

Valenciaga, D., Chongo, B., Herrera, R.S., Torres, V., Oramas, A. \& Herrera, M., 2009. Effect of regrowth age on in vitro dry matter digestibility of Pennisetum purpureum cv. CUBA CT-115. Cub. J. Agric. Sci. 43, 79-82.

Waghorn, G.C. \& Clark, D.A., 2004. Feeding value of pastures for ruminants. New Zealand Vet. J. 52, 320-331.

Wanapat, M., Cherdthong, A., Phesatcha, K. \& Kang, S., 2015. Dietary sources and their effects on animal production and environmental sustainability. Anim. Nutri. 1, 96-103.

Waters, K.M., DiLorenzo, N. \& Lamb, G.C., 2013. Understanding the effects of forage composition and structure in ruminant nutrition. Department of Animal Sciences, Florida Cooperative Extension Service, Institute of Food and Agricultural Sciences, University of Florida. http://edis.ifas.ufl.edu. Accessed 06 October 2016

Woodward, S.L., Waghorn, G.C. \& Laboyrie, P.G., 2004. Condensed tannins in bird's foot trefoil (Lotus corniculatus) reduce methane emissions from dairy cows. Proceedings of the New Zealand Society of Animal Production 64, 160-164.

Yisehak, K., Johan, D. \& Janssens, G.P.J., 2014. Effects of supplementing tannin-rich diets with polyethylene glycol on digestibility and zootechnical performances of zebu cattle bulls (Bos indicus). J. Anim. Phys. Anim. Nutri. 98, 431438. 